\title{
Global Geotourism - An Emerging Form of Sustainable Tourism
}

Ross K. Dowling / e-mail: r.dowling@ecu.edu.au

Edith Cowan University, Australia

Dowling, R. K. (2013). Global Geotourism - An Emerging Form of Sustainable Tourism. Czech Journal of Tourism, 2(2), 59-79.

DOI: 10.2478/cjot-2013-0004.

\begin{abstract}
Geotourism is a new form of tourism based on the geological environment. Whilst ecotourism and biodiversity have been described in the academic literature for over thirty years, geotourism and its attendant concepts of geoheritage, geodiversity, geoconservation, and geotours, is relatively new. Geotourism is defined as tourism which focuses on an area's geology and landscape as the basis of fostering sustainable tourism development. It begins with an understanding of the Abiotic (non-living) environment, to build greater awareness of the Biotic (living) environment of plants and animals as well as the Cultural environment of people, past and present. It is argued that geotourism offers a new form of sustainable tourism which is more holistic than previous niche forms of tourism.
\end{abstract}

\section{Keywords}

geological tourism, geotourists, geoparks sustainable development

JEL classification: Y80, L83 / Accepted: 29 October 2013 


\section{Introduction}

It has been suggested that greater attention should be paid to environmentally innovative forms of tourism which foster both environmental and social responsibility (Pásková, 2012). One new emerging type of tourism which is 'environmentally innovative' is geotourism. An early definition of geotourism as strictly 'geological tourism' has subsequently been refined as a form of tourism that specifically focuses on geology and landscape. It promotes tourism to geo-sites and the conservation of geodiversity and an understanding of earth sciences through appreciation and learning. This is achieved through visits to geological features, use of geo-trails and view-points, guided tours, geo-activities and patronage of geosite visitor centres. Geotourists can comprise both independent travellers and group tourists, and they may visit natural areas or urban/built areas wherever there is a geological attraction. This is a key distinction between geotourism and other forms of natural area tourism as by definition natural area tourism takes place only in natural areas (Figure 1).

Figure 1 The relationship of geotourism with other forms of tourism. Solid and dashed lines represent interconnecting pathways. The connection between ecotourism and geotourism is represented as a particularly strong relationship

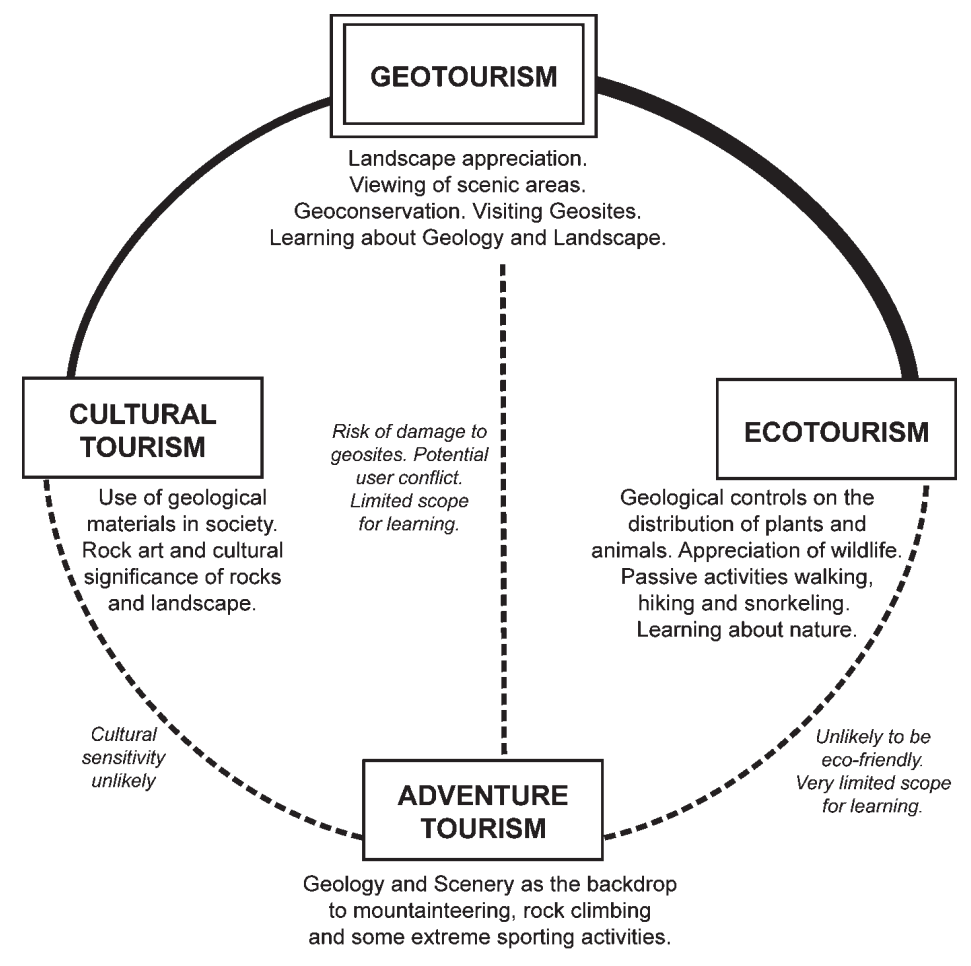

Source: Newsome and Dowling (2010) 
Thus, geotourism is sustainable tourism with a primary focus on experiencing the earth's geological features in a way that fosters environmental and cultural understanding, appreciation and conservation, and is locally beneficial. It is about creating a geotourism product that protects geoheritage, helps build communities, communicates and promotes geological heritage and works with a wide range of different people. Geology is the study of the earth while geomorphology is the study of landforms. Natural resources include landscapes, landforms, rock outcrops, rock types, sediments, soils and crystals. The 'tourism' part means visiting, learning from and appreciating geosites. Overall, geotourism comprises the geological elements of 'form' and 'process' combined with the components of tourism such as attractions, accommodation, tours, activities, interpretation as well as planning and management (Figure 2).

Figure 2 Conceptualization of the nature and scope of geotourism

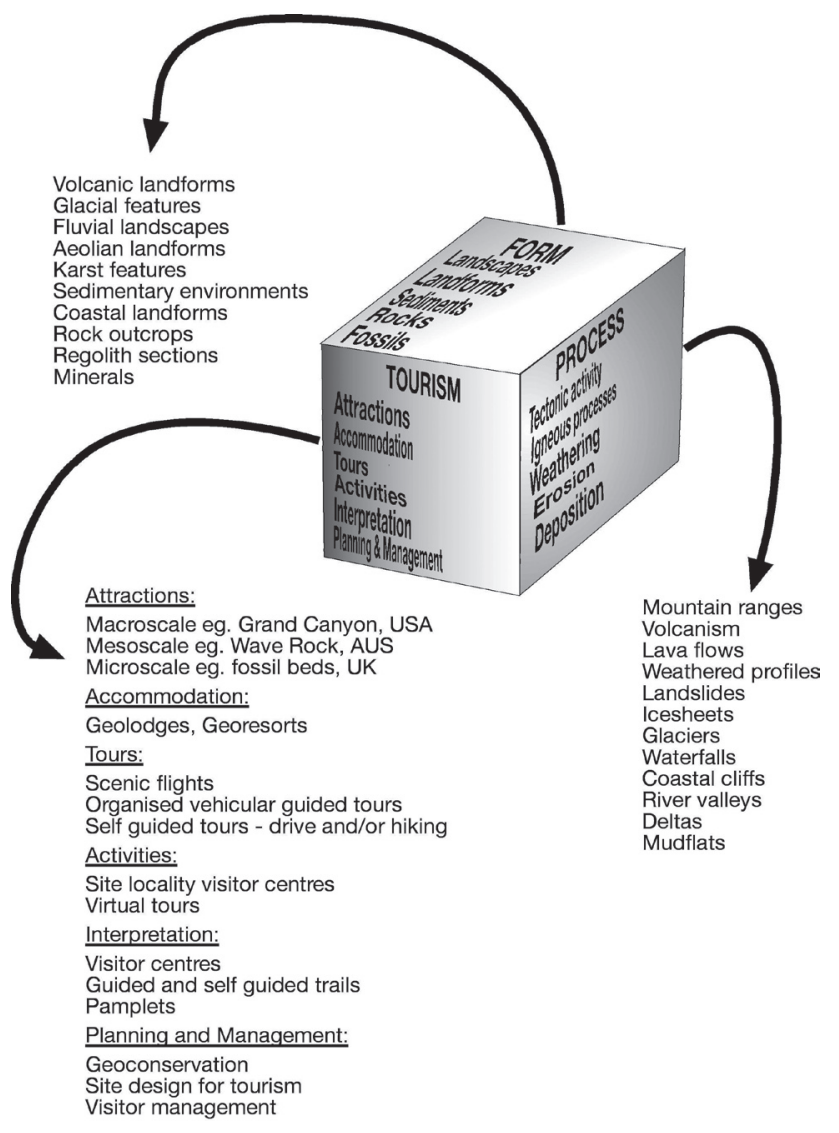

Source: Dowling and Newsome (2006)

Geotourism attractions are now being developed around the world, primarily as a sustainable development tool for the development of local and regional communities. 
A major vehicle for such a development is through UNESCO's 'geoparks'. A geopark is a unified area with geological heritage of international significance and where that heritage is being used to promote the sustainable development of the local communities who live there (UNESCO, 2011). Geoparks evolve through a series of levels from 'aspiring', 'national', 'regional' (eg. European or Asia-Pacific Regions, to 'global'. There are nowadays 100 global geoparks in 29 countries. A geopark achieves its goals through conservation, education and tourism. It seeks to conserve significant geological features, and explore and demonstrate methods for excellence in conservation and geoscientific knowledge.

\section{Defining Geotourism}

Travel to areas of outstanding natural landscapes or unique landforms is not new. However, the concept of geotourism has only occurred in relatively recent times and it has been defined by two different standpoints, that is, geotourism being defined as either 'geological' or 'geographical' tourism. The former has been characterised by geologists, the latter by the National Geographic Society. This has led to confusion surrounding the definition of geotourism.

The first published definition of geotourism as geology based tourism, defined it as the provision of interpretive and service facilities to enable tourists to acquire knowledge and understanding of the geology and geomorphology of a site (including its contribution to the development of the Earth sciences) beyond the level of mere aesthetic appreciation (Hose, 1995). Further refinements were made by Hose (2000, 2008, 2012). Inherent in these definitions is that geotourism is a vehicle to foster geoconservation, understand geological heritage (geoheritage), and appreciate geological diversity (geodiversity). Taken together the notion is that geotourism as a form of tourism is underpinned by the concept of sustainability.

Geodiversity now stands alongside biodiversity as an important element of landscape appreciation, including its conservation. This has importance for geotourism. Through the investigation of geology's form, process and time, we can gain an understanding of the complexity of process systems and history. By using these principles within chronologies of landscape change, studies of geodiversity can become a valuable tool in understanding sustainable geotourism (Thomas, 2012). It has been suggested that there needs to be a shift away from traditional approaches to geological interpretation towards a more experiential involvement to ennable people to rediscover their geoheritage through new and memorable experiences, which helps the geoconservation community to engage with a wider audience (Gordon, 2012). He argues that 'from a geoconservation perspective, therefore, if people have a deeper awareness and connection with their geoheritage through more meaningful and memorable experiences, they are more likely to value it and help to manage it sustainably' (p. 74).

Newsome and Dowling (2010) described geotourism as a form of tourism that specifically focuses on geology and landscape. Unlike ecotourism, which by definition can only take place in natural areas, they argued that geotourism can occur in either natural or 
human modified environments. It is viewed as promoting tourism to geological sites (geosites), the conservation of geological diversity (geodiversity), and an understanding of earth sciences through appreciation and learning. This is achieved through independent visits to geological features, use of geological trails (geotrails) and view points, guided tours, geo-activities and patronage of geo-site visitor centres. This definition also embraced the broader aspects of tourism activity in that visitation to geotourism destinations, whether by independent travellers or tour groups, requires transport, access, accommodation and services, trained staff, planning and management.

Hose (2012) outlines the historical and theoretical underpinnings of geotourism and approaches to its sustainable management. He suggests that it is underpinned by three key interrelated aspects (the ' $3 \mathrm{G}$ 's') of modern geotourism, that is, geoconservation, geohistory and geo-interpretation. Based on this $3 \mathrm{G}$ approach, geotourism is then defined as 'The provision of interpretative and service facilities for geosites and geomorphosites and their encompassing topography, together with their associated in situ and ex situ artefacts, to constituency-build for their conservation by generating appreciation, learning and research by and for current and future generations' (Hose \& Vasiljević, 2012: 38-39).

While geotourism (essentially 'geological' tourism) was being characterised in England and Australia by academic researchers in the 1990s and 2000s, in the United States of America the National Geographic Society was promoting a broader 'geographic' view of geotourism that embraced a broader remit and included a range of niche forms of tourism such as cultural tourism and ecotourism. It stated that 'geotourism was defined as tourism that sustains or enhances the geographical character of a place - its environment, culture, aesthetics, heritage, and the well-being of its residents (National Geographic, 2005). Here the term environment was taken to include geology although this was not explicitly stated. The National Geographic definition incorporated the concept of sustainable tourism and, in a similar vein to ecotourism, asserted that tourism revenue should promote conservation, and extended it to culture and history as well, that is, all distinctive assets of a place.

Around the same time geotourism was also being defined as a new form of tourism which is 'a multi-interest kind of tourism exploiting natural sites and landscapes containing interesting earth-science features in a didactic and entertaining way' (Pralong, 2006: 20). It was described as being based on imagination and emotion, favouring experience and sensations, and explaining the natural environment through its temporal and spatial dimensions to provide opportunities for economic development. This form of tourism was carried out through 'striking' and 'original' on-site interpretation promoted through 'geomarketing'.

Following this approach, an International Congress of Geotourism held at Arouca, Portugal in 2011 under the auspices of UNESCO, recognized the need to clarify the concept of geotourism. It adopted the geographic version of the definition, but for the first time included in it the term 'geology'. A declaration released at the end of the conference stated that 'geotourism should be defined as tourism which sustains and enhances the identity of a territory, taking into consideration its geology, envi- 
ronment, culture, aesthetics, heritage and the well-being of its residents (Arouca Declaration, 2011). In this definition, geological tourism is viewed as one of the multiple elements of geotourism.

The major difference between the 'geological' and 'geographical' versions of the definition is that the former focuses on geotourism as a 'form' or type of tourism whereas the latter views geotourism as an 'approach' to tourism, somewhat akin to sustainable tourism. Neither view is mutually exclusive as geotourism (from a 'geological' perspective) naturally encompasses the geotourism principles as espoused by National Geographic. This is in exactly the same way that ecotourism (a form of tourism) not only incorporates sustainable tourism principles, but in fact should be a best practice exemplar of it. In essence the National Geographic view of geotourism seems to simply be the application of sustainable tourism principles combined with the element of an area's 'sense of place'. The best way forward is to view geotourism both as a form of tourism as well as an approach to it, but one that firmly ties itself first to the geologic nature of an area's 'sense of place'.

Thus, applying these factors to a combined definition, geotourism is defined as 'tourism which focuses on an area's geology and landscape as the basis of fostering sustainable tourism development' (Dowling, In Press). Such tourism development generates benefits for conservation (especially geoconservation), appreciation (through geoheritage interpretation), and the economy. Essential to the development of geotourism is the understanding of the identity or character of a region or territory. To achieve this, geotourism is viewed as being based on the idea that the environment is made up of Abiotic, Biotic and Cultural components. This 'ABC' approach comprises the Abiotic elements of geology and climate, the Biotic elements of animals (fauna) and plants (flora), and Cultural or human components, both past and present (Figure 3). Geotourism argues that to fully understand and appreciate the environment, we must know about the Abiotic elements of geology and climate first as these determine the Biotic elements of animals and plants which live there. By extension, the combination of the Abiotic and Biotic components of the environment determine the Cultural Landscape of how people lived in the area in the past, as well as how they live there today, at present.

This is the essence of geotourism which starts with the understanding of geology interpreted through its components of Form (landforms and landscape), Process (how the landforms originated) and Time (when these processes occurred and how long they lasted). This forms the basis of a more holistic understanding of the environment and its component parts and thus, provides the residents or tourists with a greater connection to the environment in which they live or are visiting.

Therefore, geotourism is an emerging form of sustainable tourism with a primary focus on experiencing the earth's geological features in a way that fosters environmental and cultural understanding, appreciation and conservation, and is locally beneficial. The sustainable nature of geotourism is founded on the basis of its promotion of geoconservation (the conservation of the earth's geological features), its fostering an appreciation and understanding of our Earth heritage through appropriate interpretation, and its benefits to local communities through the economic benefits generated through geo- 
tourism. It has links with ecotourism and cultural tourism, but is not synonymous with either of these forms of tourism. It is about creating a geotourism product that embeds geoconservation, communicates and promotes geological heritage, and helps build sustainable communities through appropriate economic benefits.

Figure $\mathbf{3}$ Geotourism is best viewed as both a Form of tourism as well as an Approach to it. It is made up of Abiotic, Biotic and Cultural (ABC) components. When describing geotourism, it is important to include the components of Form (landforms and landscape), Process (how the landforms originated) and Time (when these processes occurred and how long they lasted)

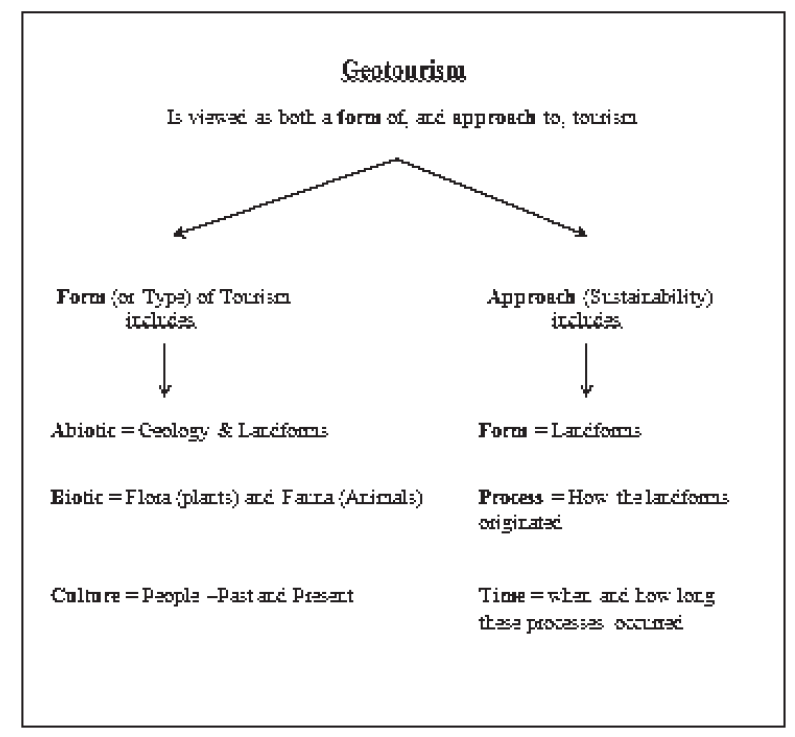

Source: Dowling (in press)

\section{Geotourism's Characteristics}

Geology is the study of the earth while geomorphology is the study of landforms. Natural resources include landscapes, landforms, rock outcrops, rock types, sediments, soils and crystals. Tourism, in a geological sense, encompasses visiting, learning from and appreciating geosites. Overall, geotourism comprises the geological elements of 'form' and 'process' combined with the components of tourism such as attractions, accommodation, tours, activities, interpretation as well as planning and management.

Geotourism may be further described as having a number of essential characteristics. These elements combine to shape geotourism in its present form. It comprises a number of interrelated components, all of which should be present for authentic geotourism to occur. There are three key principles which are fundamental to geotourism. They are that geotourism is geologically-based (that is, based on the earth's geoheritage); sustai- 
nable (i.e. economically viable, community enhancing and fosters geoconservation); and educative (achieved through geo-interpretation). All three characteristics are considered to be essential for a product to be considered an exemplar of geotourism.

Geotourism can be described according to key principles that are common to other sustainable forms of tourism. Its characteristics are being geologically focused, environmentally educative and fostering local community benefits. The goal of geotourism is to foster tourism development opportunities whilst at the same time ensuring the conservation and/or protection of geoheritage attributes (Newsome, Dowling, \& Leung, 2012). It is here that the stakeholders become important because they are the ones with either real or perceived 'ownership' of the geological features. Tourists who participate in geotours are generally interested in interacting with local communities as well as viewing landforms and other geological features. This occurs when they interact with local people through viewing geo-attractions or participating in related activities. Local guides are often especially highly valued by geotourists as they can provide an enhanced understanding of the surrounding abiotic, biotic and cultural environment (Mao, Robinson, \& Dowling, 2009).

Community involvement in tourism has increased due to its perceived local economic, social and conservation benefits and geotourism development offers local residents income generation, jobs and skill development (Farsani, Coelho, \& Costa, 2011). Thus, geotourism may be viewed as a way in which geology can be conserved and managed, largely through the efforts of local people and other stakeholders. In the tourism context being explored here, however, geology is the centrepiece and the geological focus is where geotourism clearly differs from other forms of tourism. The emphasis on geology requires specialist knowledge in presenting a site for public access and managing potential negative impacts, managing the site in terms of geoconservation, and providing stimulation in the form of education.

Therefore, geotourism is described as having a number of essential characteristics. These elements combine to shape geotourism in its present form. It comprises a number of interrelated components, all of which should be present for authentic geotourism to occur (Dowling, 2011). There are five key principles which are fundamental to geotourism. They are that geotourism is geologically-based (that is, based on the earth's geoheritage), sustainable (i.e. economically viable, community enhancing and fosters geoconservation), educative (achieved through geo-interpretation), locally beneficial, and generates tourist satisfaction. The first three characteristics are considered to be essential for a product to be considered 'geotourism' while the last two characteristics are viewed as being desirable for all forms of tourism.

Geotourism is based on the earth's heritage with a focus on its geological forms (features) and/or processes. Unlike ecotourism which occurs in, and depends on, a natural setting, geotourism may occur in either a natural or an urban setting. The focus on the earth and its geological features (at a range of scales from rock outcrops to entire landscape vistas), is essential to the planning, development and management of geotourism. It also fosters economic viability, community enhancement and geoconservation. The challenge to geotourism in any region or country is to develop its tourism capacity and 
the quality of its products without adversely affecting the geo-environment that maintains and nurtures it. Thirdly, Earth education and geo-interpretation are important tools in creating an enjoyable and meaningful geotourism experience. Geotourism attracts people who wish to interact with the earth environment in order to develop their knowledge, awareness and appreciation of it. By extension, geotourism should ideally lead to positive action for the earth by fostering enhanced conservation awareness. A fourth factor in geotourism is that it encompasses the involvement of local communities and not only benefits the community and the environment but also improves the quality of the tourist experience. Local communities can become involved in geotourism operations, and in the provision of knowledge, services, facilities and products. Geotourism can also generate income for resource conservation management, in addition to social and cultural benefits. The contribution may be financial with a part of the cost of the tour helping to subsidize a geoconservation project. Alternatively, it could consist of practical help in the field with the tourists being involved in geological data collection and/or analysis.

\section{Geotourists}

Whilst geotourism may be able to be defined, it is harder to say exactly who a geotourist is. There are some studies outlining the negative impacts on geo-sites as a result of mass and/or uncontrolled tourism (eg. Calaforra et al., 2002; Hose, 2005; Dowling \& Newsome, 2006; Hose, 2007; Burne \& Chapple, 2008; King, 2010). However, there are few studies relating directly to geotourism and even fewer which identify geotourists (Hose, 2007; Kim et al., 2008; Mao et al., 2009; King, 2010). Grant (2010) has suggested that there should be a spectrum of geotourists from general 'visitors' who either have no or limited awareness of geological tourism, to 'geo' tourists who range from geo-amateurs, to geo-specialists to geo-experts. However, geotourists are classified; their satisfaction with the geotourism experience is essential to the long-term viability of the geotourism industry. The importance of visitor safety in regard to site visits is also included in this concept . In addition, information provided about geotourism opportunities should accurately represent the opportunities offered at particular geotourism destinations. The geotourism experience should match or exceed the realistic expectations of the visitor. Client services and satisfaction should be second only to the conservation and protection of what they visit. In a recent study of experiential tourism undertaken at Wudalianchi Global Geopark, China indicated that the development of experiential tourism was of great importance in the promotion local community involvement, the sustainable development of a region's economy, the popularization of earth science knowledge, and the protection of geoheritage (Limei \& Yu, 2013).

Trying to ascertain the motivation of geotourists to participate in geotourism has been the focus of several recent studies in Australia (Allan, Dowling, \& Sanders, 2011; Hurtado, Dowling, \& Sanders, In Press). Studies of 119 tourists at Yanchep National Park in Western Australia found that the motivations to undertake a tour of one of the park's major geotourism attractions, a tour of the Crystal Cave, included curiosity (52 \%) and 
education (47\%) (Figure 4). Other key motivational factors included being brought to the cave by family or friends $(20 \%)$ and having an interest in caves (19\%). Forty-three per cent of participants indicated that the cave was the main reason for visiting the park, and more than half (74\%) indicated an interest in participating in another cave tour.

Figure 4 Crystal Cave, Yanchep National Park, Western Australia. A tour guide interacting with school students and illustrating the colour and density of a stalactite

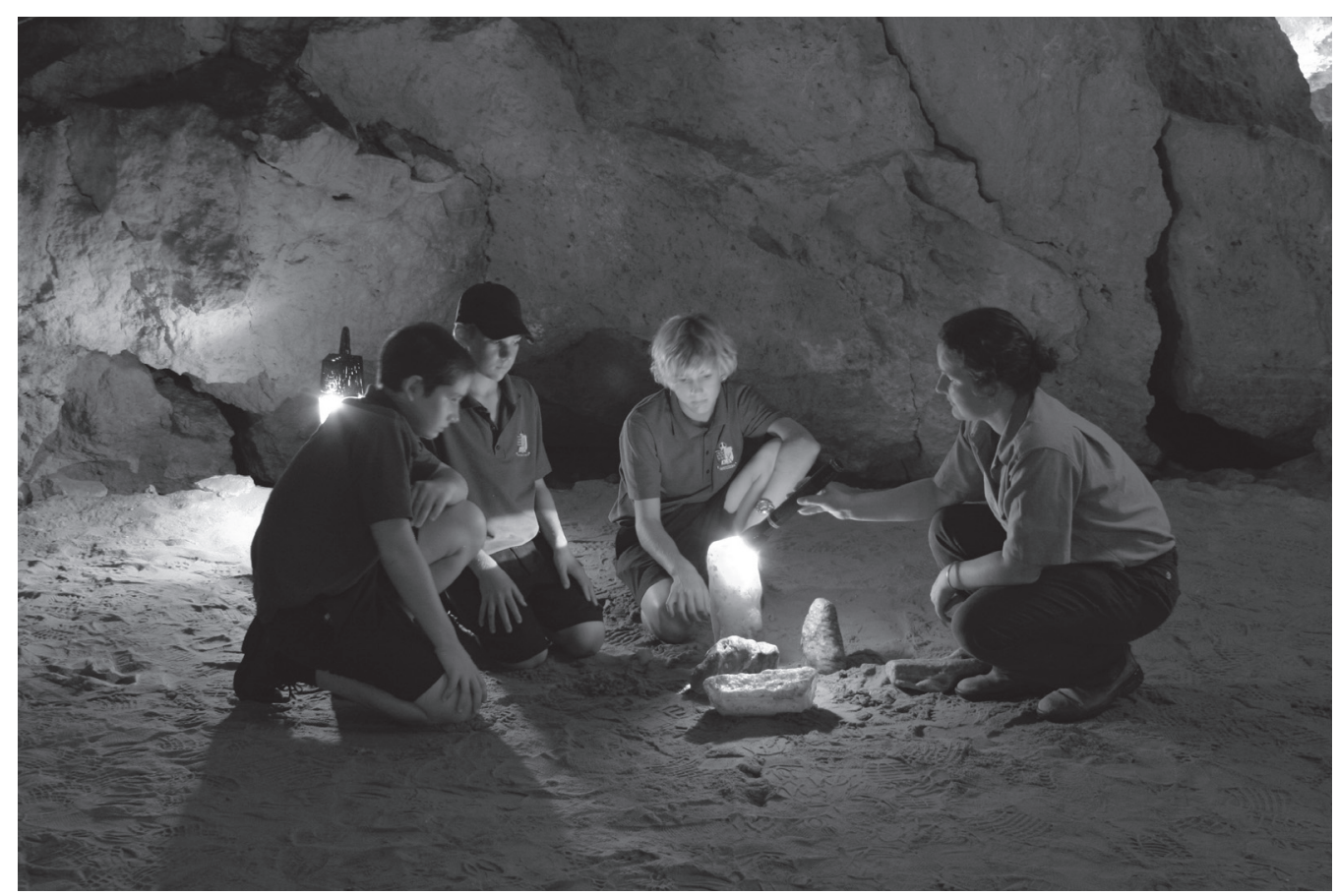

Photo: Department of Parks \& Wildlife, Western Australia

Further research based on the cultural tourism typology model (McKercher, 2002) discovered a number of geotourist types. They include:

1. The purposeful geotourist whose main motivation for travel is to visit a geo-site, and have a positive experience.

2. The intentional geotourist whose motivation is influenced by the geo-site having a positive experience and enjoying the information delivery.

3. The serendipitous geotourist for whom geotourism plays a moderate role in the decision to visit a geo-site.

4. The accidental geotourist whose motivation is not influenced by geotourism, and who may not even be aware of the geo-site prior to visitation.

5. The incidental geotourist for whom geotourism plays no meaningful role in destination choice, and the experience encountered is negative. 
The emergence of a specific geotourist typology model provides a better understanding of the segments within this niche tourism market and will contribute to more specific geotourism product development and marketing. It can also provide an insight into destination choice, which can be used to build a competitive advantage.

A further study of 110 geotourists to Crystal Cave found that tourist motivation is at the core of tourists' behaviour. The results of this study showed that the geotourism experience at Crystal Cave represented a high level of fulfilment in regard to the need for autonomy, competence and relatedness (Allan, Dowling, \& Sanders, 2011). It discovered that the intrinsic motivation and extrinsic motivation correlated positively with the likelihood of revisiting the geosite. Taken together, these results suggest that the ideal outcome of successful geotourism experiences should be in the fulfillment of the tourist needs, thus increasing the level of the likelihood of their re-visitation. This correlates to the intrinsic and extrinsic motivations of the tourist. It can therefore be assumed that the status quo of geotourism as a new form of tourism requires more focus on repeat visitations. Whereas geotourism has existed for less than two decades, retaining the first time tourists or geotourists is more effective than promoting the geosites to new tourists, particularly as the value of the geotourism experience will still not be popular with some types of tourists.

\section{Geotourism Case Studies}

Geotourism is now being used as a vehicle to foster sustainable tourism development in a number of regions around the world. At the 3rd Asia Pacific Geoparks Network Conference held in Jeju Island, Korea, in 2013, a number of papers were presented on how geotourism is providing sustainable benefits in a range of ways in a number of countries. These include developing geotourism to support - geoheritage in Malaysia (Badang \& Unjah, 2013) and Korea (Lim, 2013), geoconservation in Indonesia (Racmat \& Sita, 2013) and China (Li, 2013), geodiversity in Taiwan (Lee, 2013), geo-education in Germany (Frey, 2013), Japan (Terai, 2013) and Hong Kong (Choi, 2013), art in Norway (Rangnes, 2013), indigenous cultural values in Vietnam (Ly, 2013), and sustainable development in China (Zhang et al., 2013) and Malaysia (Ghani, Leman, \& Komoo, 2013). Other examples are now provided for Iceland, Australia and Malaysia.

\section{Iceland - volcano tourism}

Iceland is a synonym for geological tourism. Sitting astride the Mid-Atlantic Ridge, the country has 22 active volcanoes, 250 geothermal areas, 780 hot springs, and the world's third largest icecap. It is one of the world's most active hot-spots with one-third of all the lava to surface on earth in the last 1000 years being of Icelandic origin. The country has two World Heritage Regions, four national parks and 80 nature reserves, and one geopark, Katla Global Geopark.

Iceland's volcanoes include Eldgjá, and Eldfell and Laki and recent eruptions include the new island of Surtsey (which rose above the ocean in a series of volcanic eruptions 
between 1963 and 1968), Eldfell (on the island of Heimaey in 1973), Hekla (which produced a series of powerful earthquakes which shook the country in 2000), and Eyjafjallajökull (the 'volcano that stopped the world' in 2010). The volcano has now become a popular destination for geotourists. Thousands of people from all over the globe have made the journey to the tiny island of Iceland to see the magnificent volcano, providing not only a once-in-a-lifetime opportunity for the visitors but a booming economy for the locals.

Before its eruption in March and April 2010, Eyjafjallajökull had very few visitors. The people that visited the spectacular wonder were either scientist or adventurists, not many people would go out of their way to see the dormant volcano covered in a glacier. Now thousands of people come from all over the world to see the volcano that stopped the world. During its initial eruption, hundreds of people from all over the world flocked to the volcano to watch the spectacular view. Icelandic tourism companies began to offer special deals that allowed visitors to view the volcano and three helicopters on standby waiting to take tourists on a tour over the volcano. Today geological tourism and adventure and scientific tours have been created to specifically experience Eyjafjallajökull and existing tours have also been altered to include a visit to the volcano.

At the foot of Eyjafjallajökull is Porvaldseyri, a farm owned by a famer and his wife. On April $14^{\text {th }}$ 2011, one year after the eruption, they opened up a visitor centre whose goal is to educate people not only about the eruption, but also about the geology and history of Eyjafjallajökull and other volcanos on Iceland. The aim of the Eyjafjallajökull Erupts Visitor Centre is to give the visitors a personal feeling as to what it is like to live at the foot of an active volcano. Inside the centre there is an interpretive wall illustrating the eruption with photos and text (Figure 5). The Centre also has a small theatre showing a DVD which depicts the eruption as well as the challenges and hardships the family faced during and after it. The theatre seats 60 people and the film's narration is available in seven different languages; English, Spanish, French, Norwegian, German, Italian and Icelandic. Admission is approximately seven Euro and children under 12 are free. The centre is open daily from April through to September, and at the weekends from October through to March. The Eyjafjallajökull Erupts Visitor Centre is an excellent geotourism attraction and today visitors come from all over the world to see the volcano and visit the Centre.

Other geotourism attractions in Iceland include 'The Rift' in Eldborg, an exhibition of geology, geothermal heat and energy conservation is brought to life through multimedia displays. Also close by, there is the 'Blue Lagoon', one of Iceland's major tourist attractions with approximately 170,000 visitors per annum. It is a geothermal spa supplied by hot water from the Svartsengi Geothermal Project, which supplies hot water to the Reykjanes Peninsula. The super-heated seawater is rich in blue-green algae, mineral salts and fine silica mud giving it a bright blue colour. The waters are surrounded by black lava with the steam rising from the geothermal plant adding to the surreal setting. While more of a spa setting than a geotourism one, nether-the-less, the fabulous geological setting provides tourists with an incredible geologically inspired experience enhanced by its Lava Restaurant, which is built into the cliff and featuring a natural lava wall. Also on 
Figure 5 Interpretive Panel in the Eyjafjallajökull Erupts Visitor Centre, eastern Iceland

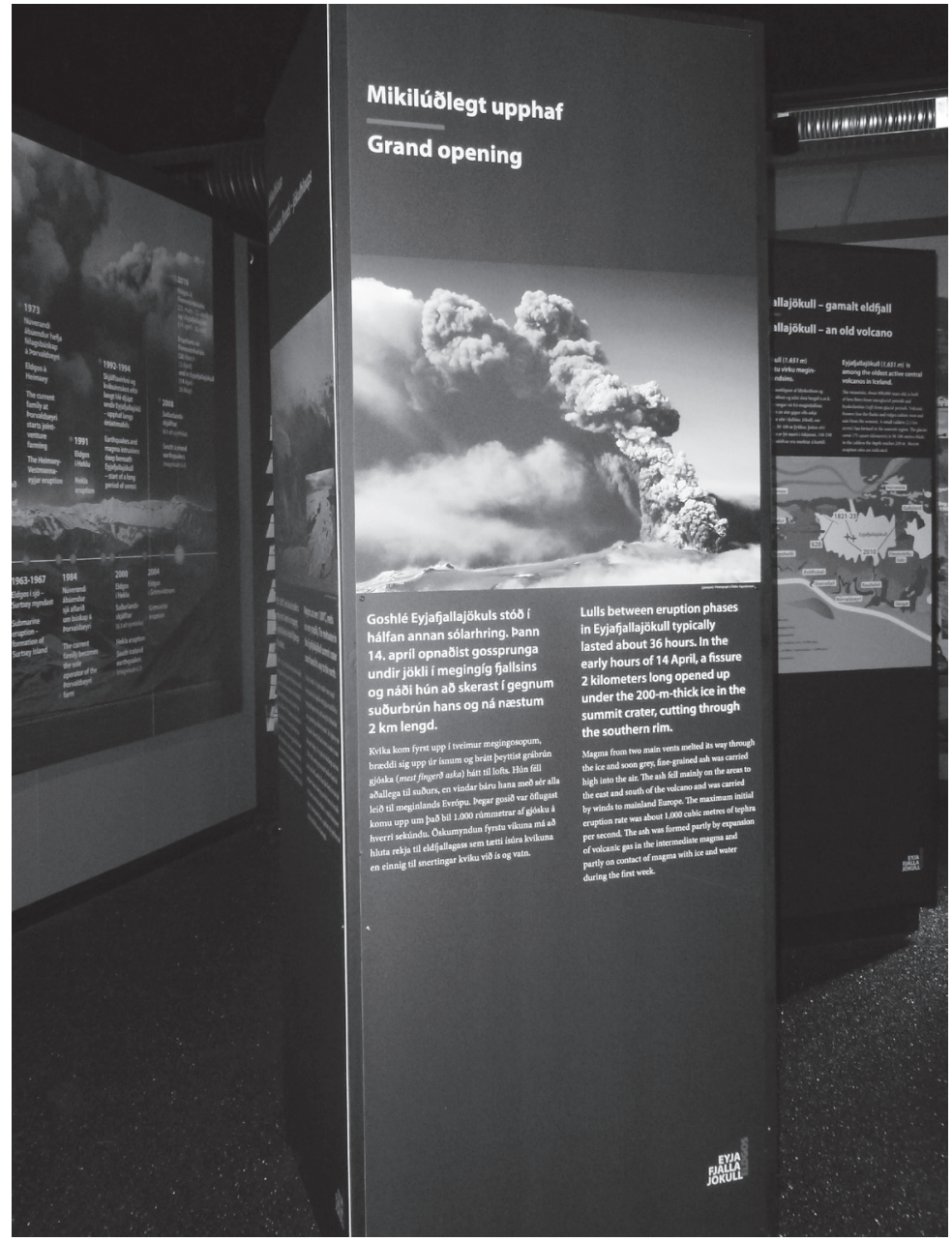

Photo: Dowling (2011)

the Reykjanes peninsula there lies/tourists can admire the 'Bridge Between Two Continents', a remarkable geotourism attraction. It is situated on the lava-scarred peninsula where two of the Earth's tectonic plates split (Figure 6). The 'bridge' spans across these two continents and is situated in the Alfagja rift valley, a chasm marking the boundary of the Eurasian and North American continental tectonic plates. Crossing the bridge takes you from North America to Europe.

On the main island of Heimaey in the Vestmannaeyjar Islands, off the southern coast of Iceland, a volcanic eruption in 1973 formed a new mountain, the red cinder cone Eldfell 'Fire Mountain'. One third of the town on the island was buried beneath the lava flow and the island increased in size by $2.3 \mathrm{sq} \mathrm{km}$. Today the resulting cinder cone is a major tourist drawcard and has given rise to the local tourist attraction of 
Figure 6 The 'Bridge Between Two Continents', a remarkable geotourism attraction on Reykjanes peninsula, Iceland. The bridge joins the Eurasian and North American continental tectonic plates. Crossing the bridge takes you from Europe to North America

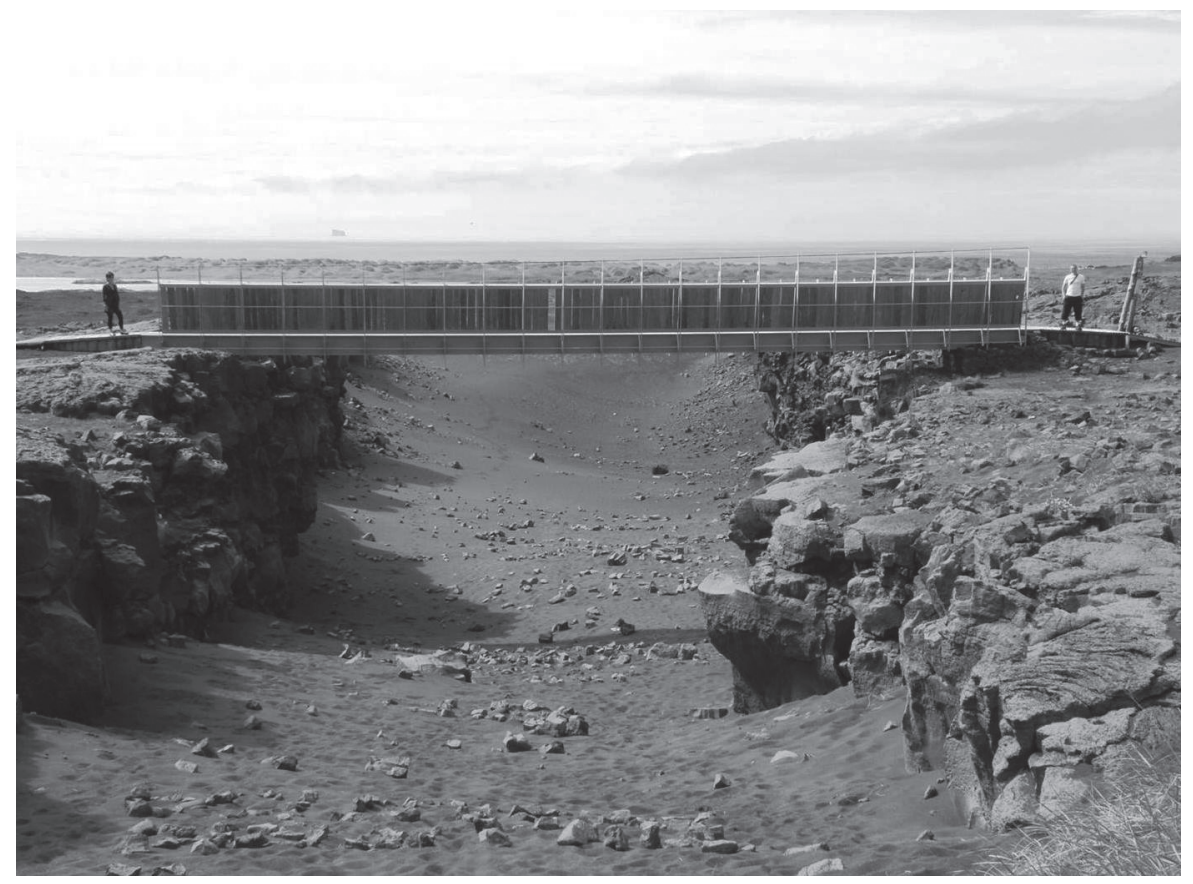

Photo: Dowling (2008)

a Volcanic Film Show which focuses on the eruption. Currently, the local council is developing an exciting geotourism attraction called 'Eldheimar - World of Fire'. It is based on the eruption, causing its 5,000 inhabitants to flee to the mainland. The eruption continued for five months engulfing 400 houses in lava and tephra. The attraction is based on the excavation of fourteen former Islander's houses which were buried in tephra by the eruption. Inside the houses there are all of their contents which were buried four days after the eruption commenced. At present excavations have commenced and the tops of some houses are exposed. Interpretive signs have been erected and it is already attracting many visitors. The excavation project has been called 'The Pompeii of the North'.

Iceland is abundant with volcanic activity, mountains, rock outcrops and peninsulas and is one of the most impressive geological destinations in the world. Here geotourism will continue to grow and expand as an iconic tourist destination which not only leaves tourists with a unique geological experience but also benefits the local economy and community. 


\section{Australia - cave tourism}

Australia is home to many geological features as it is the oldest of the continents. The country is a pioneer in geotourism development and the country held the Inaugural Global Geotourism Conference in 2008. In recent years it has established a Geotourism Subcommittee of the Geological Society of Australia a Geotourism Forum within the tourism industry organisation, Ecotourism Australia, and awareness with the Australasian Institute of Mining and Metallurgy (AusIMM; Robinson, 2011). Ngilgi Cave was first discovered in 1899 and in 1900 it was opened as a show cave to tourists. In 1903 it became the first cave in Western Australia to have electric lights installed in 1903, and the booming popularity of the cave tours resulted in the construction of a nearby Caves Hotel in 1905. The main geological attractions in the Cave are the high quantity and variety of its decorations, particularly its shawls. However, other decorations include flowstone, stalactites, stalagmites, helictites, pendulums, straw, columns and pillars.

Inside the cave lighted boardwalks are provided for visitors through a range of chambers. There is also a cave 'crystal touch table' where samples of formations are provided for visitors to be able touch the various formations. There are a range of tours which focus on the geology, adventure or the local Aboriginal culture. Supporting the Cave attraction, visitors can take advantage of a number of amenities for tourists including a café, children's playground, barbeque facilities and walk trails. Ngilgi Cave may also be hired out for functions, weddings, photo shoots and concerts and it has been the winner in the Western Australian Tourism Awards for its facilities for tourists.

There are 350 limestone caves in the area and local Tourism Association operates three spectacular show caves - Lake, Mammoth and Jewel. A fourth cave, Moondyne, reopened to the public in late 2012 after ten years, offering visitors an intimate, exclu-

Figure 7 Interpretation at CaveWorks, Western Australia. The Centre provides information about the geology of the region focussing on the three show caves in the area

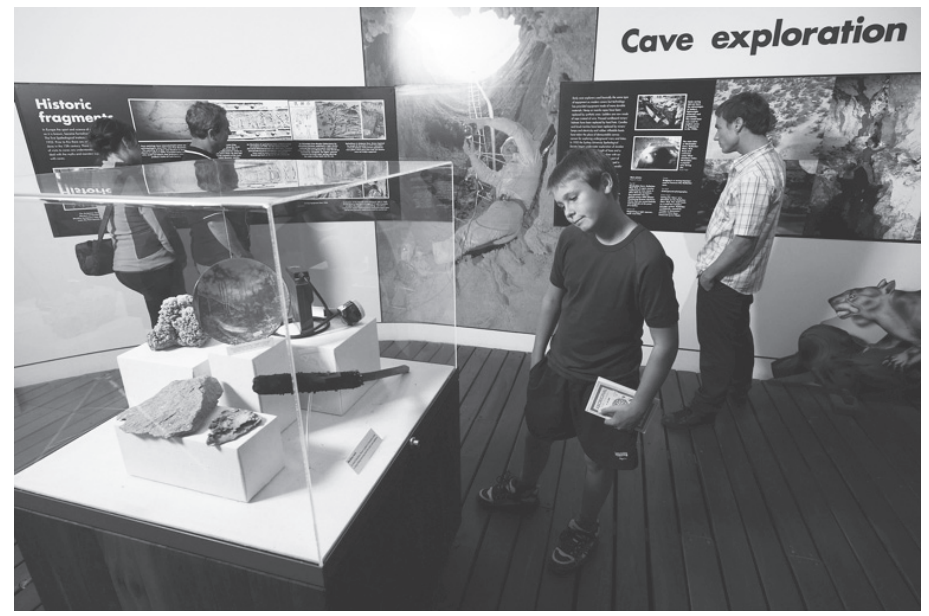

Photo: Augusta Margaret River Tourism Association, Western Australia 
sive caving experience. At Lake Cave there is an interpretative centre CaveWorks which describes the formation and history of caves within the region, throughout Australia and around the world (Figure 7). Mammoth was known to European settlers in 1850 but was not fully explored until 1895. Mammoth Cave's main attractions are its cave formation features and unique fossils. It is 500 metres long and 30 metres deep and it is well known for its fossil remains with a total of over 10,000 bones having been found in the cave, some being over 35, 000 year old. Tourists in Mammoth Cave explore the caves at their leisure using the Cave's Mp3 audio self-guiding system.

\section{Malaysia - karst tourism}

Malaysia is a land of magnificent geosites and its first geopark, the island of Langkawi, was proclaimed in 2007. Other key geosites are the World Heritage Listed Mt Kinabalu in Sabah and Gunung Mulu in Sarawak. Gunung Mulu National Park is one of the largest tourist attractions in East Malaysia, encompassing spectacular caves and karst formations in a mountainous equatorial rainforest setting (Dowling, 2009). Mulu is dominated by three mountains - Gunung Mulu (2376m), Gunung Api (1750m) and Gunung Benarat $(1585 \mathrm{~m})$. It is renowned for its high biodiversity and some of the largest and most unique limestone features in the world (UNESCO 2008). Thus, many of Mulu's greatest attractions lie deep below the surface. Hidden underneath the forested slopes of these mountains, it is one of the largest limestone cave systems in the world. The Park was established in 1974 and is situated 100km southeast of the town of Miri, close to the Brunei border. The geology of the area consists of a combination of alluvial clays, sandstone and limestone formations. The majestic Gunung Mulu rise over a mass of sandstone covering 52,865 hectares of old primary rainforest crossed by a number of fast flowing rivers. Interpretation of the karst features is outstanding with excellent interpretation signs and an informative visitor centre (Figure 8).

Gunung Mulu National Park incorporates the largest cave in the world, the longest cave passage with underground clear water constantly flowing, and the largest rock chamber in the world. Sixty to seventy percent of the caves in the region have not yet been explored. The park is extremely rich in cave resources, as a result of geological uplift in the karst formation 2-5 million years ago followed by the erosion of the karst landscape by rivers in the area. The caves that have been created are some of the largest found anywhere in the world and are superb examples of tropical river caves with flood incursions, extensive classic sediment deposits and elliptical tubes linking different cave levels.

Sarawak Chamber is the largest natural rock chamber in the world and is three times the size of the Big Room in Carlsbad Caverns National Park, New Mexico. It is 700m long, 400m wide and approximately $70 \mathrm{~m}$ high. Api Chamber is a chamber in Whiterock Cave in Gunung Api. It is the eighth largest cave chamber by area in the world. Its height is over $100 \mathrm{~m}$ and its plan area is 58,000 square meters. Over $200 \mathrm{~km}$ of cave passages have been explored but this is thought to represent just $30-40 \%$ of the actual total. It is the second largest chamber in Malaysia after Sarawak Chamber. 
Figure 8 The Visitor Centre at Gunung Mulu World Heritage Region, Sarawak, Malaysia. Park Manager Brian Clark (right) and his wife Sue (left) have developed world class geotourism interpretation here

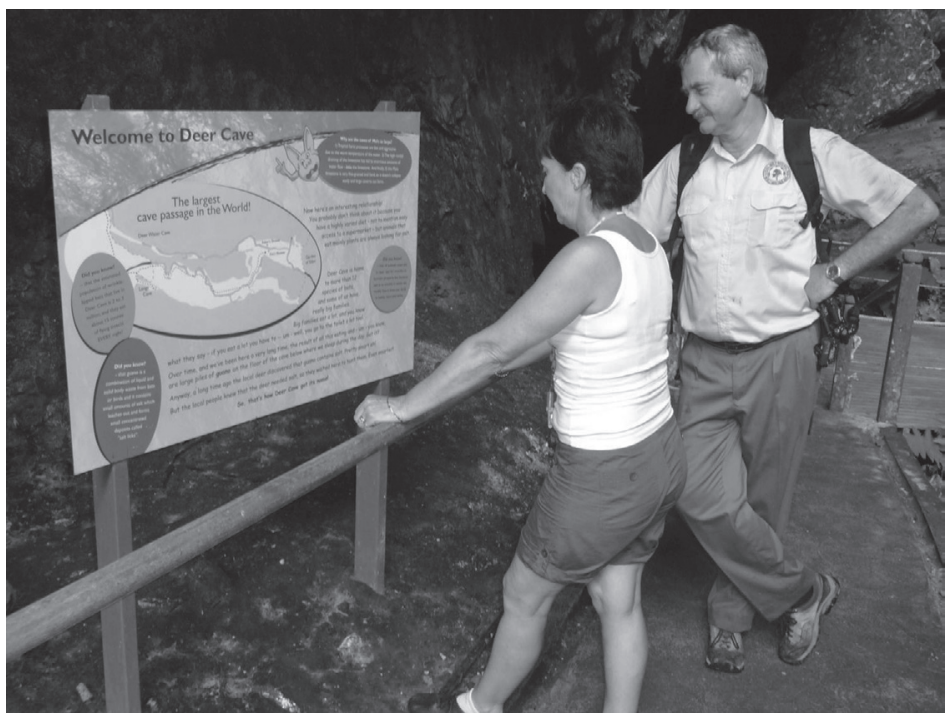

Photo: Dowling (2009)

As well as caves, razor-edged 'pinnacles' are a feature of the area, particularly on the north-east side of Gunung Api (McGinley, 2008). The pinnacles are a collection of 45m high limestone needles that cling to the side of the mountains. As water has continued to erode and dissolve the rock, the formations have taken on a razor-like appearance. They are formed in a forest of silver-grey stone encircled by thick green vegetation. A trekking trail to the area, the Pinnacles Summit Trek, is one of the most popular hikes in the park.

Another activity is the Mulu Canopy Skywalk, which is $480 \mathrm{~m}$ long and $20 \mathrm{~m}$ above the forest floor. It is the world longest tree-based walkway. It was built by the local communities with advice from experts in design and structure. The walkway winds among the treetops with a river running below and the soaring heights of nearby limestone cliffs above. It also follows a circular route suspended between fifteen trees with a separate exit tower (Francis, 1999).

Gunung Mulu National Park provides a sound example of how geotourism has brought about tangible benefits for local communities and the natural environment (Dowling, 2009). Through geotourism there has been a cross-cultural understanding of the incentive value of tourism in preserving the local traditional culture and heritage. Through tourism, especially geotourism in Mulu, local people have been provided with a reason to preserve their culture. Geotourism has brought considerable economic benefits to Gunnung Mulu in particular, and to Malaysia in general. Direct economic benefits inclu- 
de the income from entrance fees to the park, the additional fee of visiting different areas inside the park (for example, RM30 for the Canopy Skywalk), as well as through the cost from accommodation, food and souvenirs. Indirect benefits have accrued to related industries which have linkages to geotourism, for instance entertainment, employment, manufacturing, or telecommunications.

\section{Conclusion}

Geotourism has emerged as a credible sustainable tourism industry, which offers new development and employment opportunities for local people. It can generate a range of economic benefits for local communities including revenue creation, job generation, diversification and infrastructure improvement. Net benefits from tourism accrue from the balance of economic, social and environmental interactions of tourists with a destination (Greiner, Stoeckl, \& Schweigert, 2004). Any geotourism venture should only be considered successful if local communities have some measure of control over them and if they share equitably in the benefits emerging from geotourism opportunities. However, geotourism, like other forms of tourism, can generate both positive and negative impacts. Thus, the main aim of stakeholder participation is to maximise economic, social and ecological benefits and to minimise any adverse costs. By presenting income, employment and infra-structural benefits for local regions, geotourism is often presented as a mechanism having the potential to offset the local opportunity cost of protected natural areas and cultural sites. The logic for such development is that political support for conservation is best generated where protected areas demonstrate tangible economic benefit to local peoples. They argue that where people gain more from the use of landscapes through tourism, they are more likely to protect their asset and may invest further resources in to it.

One of the most obvious and immediate benefits of sustainable geotourism associated with local communities is the increase in employment opportunities and income generation for the host region. This includes:

1. direct employment (associated service industries such as hotels, restaurants, concessions);

2. indirect employment (generated as a result of increasing industry inputs such as employment at a retail souvenir outlet);

3. induced employment (generated as a result of increased spending capacity of local residents due to increased receipts from tourism; consumption of goods, for example).

Engaging local communities in geotourism development is a complex task. Developing tourism in ways that are more appropriate for communities takes considerable time and effort, participatory planning and conflict resolution procedures. A central consideration is that of inclusion of all relevant individuals and groups in the engagement process. This is important because those who want to participate in the planning of geotourism 
may have either a real or a perceived stake, and each is important. Although the range of interested stakeholders may be large, those in the local community with a direct involvement in the area are very important and need not only to be heard but also to be involved in future management if desired, once the plan is enacted. Once the issues have been addressed, then the promise of geotourism development with its associated environmental, sociocultural and economic benefits will flow in a truly sustainable manner.

\section{References}

Allan, M., Dowling, R. K., \& Sanders, D. (2011). Toward a better understanding of motivations for a geotourism experience; A self-determination theory perspective. In Gross, M. J. (Ed.), CAUTHE 2011 National Conference Tourism: Creating a Brilliant Blend (pp. 885-890). Adelaide: University of South Australia, School of Management.

Arouca Declaration. (2011). Arouca Declaration on Geotourism, November 12, 2011 Portugal. Retrieved from http://www.europeangeoparks.org/?p=223

Badang, D. A., \& Unjah, T. (2013). Communicating geoheritage: linking culture and geology in Delta Sarawak Geopark. Paper presented at the Third Asia Pacific Geoparks Network Symposium, For the Innovation of the APGN. Jeju Island, South Korea, 7-13 September.

Burne, R., \& Chapple, R. (2008). Under the boardwalk - Tourism's encounters with stromatolites. Addressing the issues of stromatolite protection and visitor management. In Dowling, R. K., \& Newsome D. (Eds.), Inaugural Global Geotourism Conference Australia 2008 'Discover the Earth Beneath our Feet' Conference Proceedings (pp. 107-112). Perth: Promaco Conventions.

Calaforra J., Fernandez-Cortes A., Sanches-Martos F., Gisbert J., \& Pulido-Bosch A. (2002). Environmental control for determining human impact and permanent visitor capacity in a potential show cave before tourist use. Environmental Conservation, 30(2), 160-167. DOI: 10.1017/ S0376892903000146.

Choi, C. (2013). The role of geopark guides in enhancing geotourism: the recommended geopark guide system in Hong Kong. Paper presented at the Third Asia Pacific Geoparks Network Symposium, For the Innovation of the APGN. Jeju Island, South Korea, 7-13 September.

Dowling, R. K. (2009). Geotourism's contribution to local and regional development. In de Carvalho, C., \& Rodrigues, J. (Eds.), Geotourism and Local Development (pp. 15-37). Idanha-a-Nova, Portugal: Camar municipal de Idanha-a-Nova.

Dowling, R. K. (2011). Geotourism's global growth. Geoheritage, 3, 1-13. DOI: 10.1007/s12371-0100024-7.

Dowling, R. K. (In Press). Geotourism. In Jafari, J., \& Xiao, H. (Eds.), Encyclopedia of Tourism. New York: Springer.

Dowling, R., \& Newsome, D. (2006). Geotourism. Oxford: Elsevier Ltd.

Farsani, N. T., Coelho, C., \& Costa, C. (2011). Geotourism and geoparks as novel strategies for socio-economic development in rural areas. International Journal of Tourism Research, 13(1), 6891. DOI: $10.1002 /$ jtr.800.

Francis, G. (1999). Mulu National Park - Walkway in the Sky. Retrieved from http://www.e-borneo. $\mathrm{com} /$ travel/articles/mulu-national-park-canopy-walkway-in-the-sky.html

Frey, M. L. (2013). Geotourism, a tool for geo-education in science societies. Paper presented at the Third Asia Pacific Geoparks Network Symposium, For the Innovation of the APGN. Jeju Island, South Korea, 7-13 September. 
Ghani, K. A., Leman, M. S., \& Komoo, I. (2013). Sustainable tourism and geoparks. Paper presented at the Third Asia Pacific Geoparks Network Symposium, For the Innovation of the APGN. Jeju Island, South Korea, 7-13 September.

Gordon, J. E. (2012). Rediscovering a sense of wonder: Geoheritage, geotourism and cultural landscape experiences. Geoheritage, 4, 65-77. DOI: 10.1007/s12371-011-0051-z.

Grant, C. (2010). Towards a typology of visitors to geosites. Paper presented at the Second Global Geotourism Conference, Making Unique Landforms Understandable. Mulu, Sarawak, Malaysia, 17-20 April.

Greiner, R., Stoeckl, N., \& Schweigert, R. (2004). Estimating community benefits from tourism: The case of Carpentaria Shire. Paper presented to the 48th Annual Conference of the Australian Agricultural and Resource Economics Society, Melbourne, 11-13 February.

Hose, T. A (2000). European Geotourism - Geological Interpretation and Geoconservation Promotion for Tourists. In Barretino, D., Wimbledon, W. P., \& Gallego, E. (Eds.), Geological Heritage: Its Conservation and Management (pp. 127-146). Madrid: Instituto Tecnologico Geominero de Espana.

Hose, T. A. (1995). Selling the Story of Britain's Stone. Environmental Interpretation, 10(2), 16-17.

Hose, T. A. (2005). Geotourism: appreciating the deep time of landscapes. In Novelli, M. (Ed.), Niche Tourism: Contemporary Issues, Trends and Cases. Oxford, UK: Elsevier Butterworth -Heinemann.

Hose, T. A. (2007). Geotourism in Almeria Province, southeast Spain. Tourism Interdisciplinary Journal, 55(3), 259-276.

Hose, T. A. (2008). Towards a history of Geotourism: definitions, antecedents and the future. In Burek, C. V., \& Prosser, C. D. (Eds.), The History of Geoconservation (pp. 37-60). London: The Geological Society.

Hose, T. A. (2012). 3G's for modern geotourism. Geoheritage, 4, 7-24. DOI: 10.1007/s12371-0110052-y.

Hose, T. A., \& Vasiljević, D. A. (2012). Defining the nature and purpose of modern geotourism with particular reference to the United Kingdom and South-East Europe. Geoheritage, 4, 25-43. DOI: $10.1007 / \mathrm{s} 12371-011-0050-0$.

Hurtado, H., Dowling, R. K., \& Sanders, D. (In Press). An Exploratory Study to Develop a Geotourism Typology Model. International Journal of Tourism Research, 15(6).

Kim, S. S., Kim, M., Park, J., \& Guo, Y. (2008). Cave tourism: Tourists' characteristics, motivations to visit, and the segmentation of their behaviour. Asia Pacific Journal of Tourism Research, 13(3), 299-318.

King, L. M. (2010). Geotourism in the Hawaiian Islands. In Newsome, D., \& Dowling, R. K. (Eds.), Geotourism: The Tourism of Geology and Landscape (pp. 114-125). Oxford, UK: Goodfellow Publishers.

Lee. C. T. (2013). Geodiversity and geotourism development in Caoling Geopark, Yunlin County, Taiwan. Paper presented at the Third Asia Pacific Geoparks Network Symposium, For the Innovation of the APGN. Jeju Island, South Korea, 7-13 September.

Li, J. (2013). Geo-heritage, geo-tourism and geo-conservation in Shennongjia Geopark, China. Paper presented at the Third Asia Pacific Geoparks Network Symposium, For the Innovation of the APGN. Jeju Island, South Korea, 7-13 September.

Lim, J. D. (2013). New conservation and interpretation approach for Korean geoheritages. Paper presented at the Third Asia Pacific Geoparks Network Symposium, For the Innovation of the APGN. Jeju Island, South Korea, 7-13 September. 
Limei, G., \& Yu, Y. (2013). On experiential tourism in geoparks. Paper presented at the Third Asia Pacific Geoparks Network Symposium, For the Innovation of the APGN. Jeju Island, South Korea, 7-13 September.

Ly, S. C. (2013). Conservation and exploitation of indigenous cultural values for construction and development of Dong Van Karst Plateau Global Geopark. Paper presented at the Third Asia Pacific Geoparks Network Symposium, For the Innovation of the APGN. Jeju Island, South Korea, 7-13 September.

Mao, I., Robinson, A. M., \& Dowling, R. K. (2009). Potential geotourists: An Australian case study. Journal of Tourism Research, 10(1), 71-80.

McGinley, M. (2008). Gunung Mulu National Park, Malaysia. Retrieved from www.eoearth.org/ article/Gunung_Mulu_National_Park,_Malaysia

McKercher B. (2002). Towards a classification of cultural tourists. International Journal of Tourism Research, 4(1), 29-38.

National Geographic (2005). Geotourism Charter http://www.nationalgeographic.com/travel/ sustainable/pdf/geotourism_charter_template.pdf

Newsome, D., \& Dowling, R. K. (Eds.) (2010). Geotourism: The Tourism of Geology and Landscape. Oxford: Goodfellow Publishers.

Newsome, D., Dowling, R. K., \& Leung, Y. F. (2012). The nature and management of geotourism: A case study of two established iconic geotourism destinations. Tourism Management Perspectives, 2-3, 19-27.

Pásková, M. (2012). Tourism Environmentalism. Czech Journal of Tourism, 1(2), 77-113.

Pralong, J. P. (2006). Geotourism: A new form of tourism untilising natural landscapes and based on imagination and emotion. Tourism Review, 61(3), 20-25. DOI: 10.1108/eb058476.

Rangnes, K. (2013). Communicating geological heritage through art - a cooperative project between geologists, artists and schools. Paper presented at the Third Asia Pacific Geoparks Network Symposium, For the Innovation of the APGN. Jeju Island, South Korea, 7-13 September.

Robinson, A. M. (2011). Geoheritage, geotourism and The AusIMM. The AusIMM Bulletin, 5, 8892.

Terai, K. (2013). Unzen Volcanic Area Global Geopark utilized by school education. Paper presented at the Third Asia Pacific Geoparks Network Symposium, For the Innovation of the APGN. Jeju Island, South Korea, 7-13 September.

Thomas, M. F. (2012). A geomorphological approach to geodiversity - its applications to geoconservation and geotourism. Quaestiones Geographicae, 31(1), 81-89. DOI: 10.2478/v10117-012-00059.

UNESCO (2008). Gunung Mulu National Park. World Heritage - United Nations Educational, Scientific and Cultural Organisation (UNESCO). Retrieved from http://www.whc.unesco.org/en/ list/1013

Zhang, J., Tian, M., Wu, F., \& Mei, X. (2013). Discussion on key points of geopark construction and development in China. Paper presented at the Third Asia Pacific Geoparks Network Symposium, For the Innovation of the APGN. Jeju Island, South Korea, 7-13 September. 